\title{
TB/HIV Pleurisy Reduces Th17 Lymphocyte Proportion Independent of the Cytokine Microenvironment
}

Vanessa C Korb a , Alisa Phulukdaree ${ }^{\text {a, } 1}$, Umesh G Lalloo a , Anil A Chuturgoon ${ }^{\text {a, b }}$, Devapregasan Moodley ${ }^{\text {a, } 2}$

${ }^{a}$ Discipline of Medical Biochemistry and Chemical Pathology, University of KwaZulu-Natal, Howard College Campus, King George V Avenue, Durban, South Africa

Institutional Mailing Address: University of KZN, Durban, South Africa, 4041

E-mail adresses:

VCK : vanessakorb@gmail.com

AP : Alisa.Phulukdaree@up.ac.za

UGL : umeshlalloo@gmail.com

DM : Devan_Moodley@hms.harvard.edu

AAC : chutur@ukzn.ac.za

${ }^{1}$ Present address: Department of Physiology, University of Pretoria, Prinshof Campus, Pretoria, South Africa

${ }^{2}$ Present address: Department of Microbiology and Immunobiology, Harvard Medical School, 77 Avenue Louis Pasteur, Boston, USA

${ }^{\mathrm{b}}$ Corresponding author: A Chuturgoon; chutur@ukzn.ac.za

Telephone number: +27312604404

Fax number: +27312604785

\section{ABSTRACT}

T-helper (Th) 17 cells are a pro-inflammatory subset of $\mathrm{CD}^{+}$effector T-cells critical in mucosal immunity. Imbalances in Th17 cell proportion have been implicated in the pathogenesis of several diseases; however, this has not been adequately explored in tuberculosis (TB) and human immunodeficiency virus (HIV) co-infection. Since Th17 cells are predominantly mucosally associated, we assessed Th17 proportion and associated microenvironment in pleural effusions from patients co-infected with $\mathrm{TB} / \mathrm{HIV}$. Our results show that $\mathrm{TB}^{+} \mathrm{HIV}^{+}$pleurisy results in significantly reduced frequency of $\mathrm{CD}^{+} \mathrm{IL}_{-}-17^{+} \mathrm{RORC}^{+} \mathrm{STAT}^{+} \mathrm{Th}^{2}$ cells compared to $\mathrm{TB}^{-} \mathrm{HIV}^{-}$ex vivo $(p=0.0054)$ and was confirmed in conditioned media studies in vitro $(p=0.0001)$. This was not 
associated with alterations in Th17 polarising cytokines IL-6, IL-21 and IL-23 or changes in Th17 signature cytokines IL-17A and F. However, the mRNA expression of Th17 signaling molecules, IL-6 ( $p=0.0022)$, IL-6R ( $p=0.0247)$, IL-1 $\beta(p=0.0022)$ and signal transducer and activator (STAT) 3 $(p=0.0022)$ were significantly upregulated. Notably, $\mathrm{TB}^{+} \mathrm{HIV}^{+}$pleural fluid contained significantly higher concentrations of IL-1 $\beta$ ( $p=0.0008)$, IL-22 ( $p=0.0115)$, IL-31 ( $p=0.0210)$, TNF- $\alpha(p=0.0251)$ and IFN- $\gamma(p=0.0026)$ than $\mathrm{TB}^{-} \mathrm{HIV}^{-}$pleural fluid ex vivo. Taken together, this suggests a reduced portion of Th17 lymphocytes in TB/HIV pleurisy is independent of locally mediated cytokine polarisation.

\section{$\underline{\text { Keywords }}$}

Tuberculosis, HIV, co-infection, Th17, IL-1 $\beta$, IL-17

\section{INTRODUCTION}

Th17 cells are a pro-inflammatory subset of $\mathrm{CD}^{+}$effector T-cells characterised by the production of IL-17A/F, surface expression of C-C chemokine receptor (CCR)6 and lineage specific transcription factor RAR-related orphan rector (ROR)C [1]. Th17 cells predominantly reside at the mucosal surfaces where they play a pivotal role in inflammatory reactions and protective immunity against intra- [2] and extracellular [3] bacterial and fungal infections. An imbalance in Th17 proportion has been implicated in the pathogenesis of TB.

Approximately one third of the global population suffers from TB; a granulomatous disease spread by the airborne pathogen Mycobacterium tuberculosis (MTB). MTB cell wall component, trehalose-6-6'-dimycolate (TDM/cord factor) has been shown to induce the production of Th17 differentiating cytokines from antigen presenting cells through a the C-type lectin Mincle pathway [4]. Conflicting studies have noted an expansion of Th17/IL-17 axis in the peripheral blood and pleural fluid [5, 6] and a reduced frequency of Th17 cells in peripheral blood [7, 8] and bronchoalveolar lavage (BAL) fluid [7] during active MTB infection, with correlation to disease severity $[5]$.

HIV is the most powerful risk factor predisposing for active TB infection which remains the number one communicable HIV-related cause of death. In South Africa, approximately $62 \%$ of TB patients are HIV positive [9]. HIV infection is characterised by chronic immune activation and systemic depletion of $\mathrm{CD}^{+}$T-cells. The preferential loss of Th17 cells from the mucosa and 
peripheral blood with reduced levels of IL-17 during HIV infection is well documented. This loss is not completely restored by antiretroviral therapy $[10,11]$ suggesting that HIV infection interferes in the generation of Th17 cells [12].

Th17 lymphocytes are significant in the pathogenesis of TB and a potential predictor of disease severity; however, data on the proportion and role of Th17 cells in TB are conflicting. Furthermore, the confounding effect of HIV co-infection on Th17 frequency has not been investigated. Notably, $40-80 \%$ of HIV-related TB is extrapulmonary, the most common form being TB pleurisy [13] and the immunological mechanisms of which are not accurately reflected systemically [14]. Taken together with the mucosal predominance of Th17 cells, this study characterised the proportion of Th17 lymphocytes and the cytokine microenvironment in TB/HIV pleurisy in vitro and ex vivo.

\section{METHODS}

\subsection{Study Population}

This study protocol was approved by the institutional Biomedical Research Ethics Committee (BF170/11). Participants were recruited at the Department of Pulmonary and Critical Care, Inkosi Albert Luthuli Central Hospital and the Department of Internal Medicine, Prince Mshiyeni Memorial Hospital (Durban, South Africa). Newly diagnosed TB patients presenting with a TB pleural effusion and concurrent HIV-infection $(n=13)$ were enrolled. Active TB infection was confirmed by clinical diagnosis with bacterial or radiographic evidence; AFB culture positive sputum or pleural fluid microscopy (Gram, Zhiel-Neelsen, Auramine), MTB DNA (Gene Xpert), pleural histology and pleural fluid cytology. The matched control group was composed of patients presenting with a non-infectious pleural effusion (malignancy, cardiac failure, end stage renal disease) and confirmed HIV seronegative $(n=8)$. Exclusion criteria included anti-tuberculosis or anti-retroviral therapy, immunomodulatory treatment and conditions. Blood and pleural fluid were sampled by routine venesection and diagnostic pleural tap respectively, after informed consent was obtained from each participant. A summary of the demographics and clinical parameters of the study population are represented in Table 1. 
Table 1: Summary of demographic and clinical parameters of the study population

\begin{tabular}{|c|c|c|}
\hline Parameter & $\begin{array}{c}\text { TB}^{-} \mathrm{HIV}^{-} \\
\quad n=8\end{array}$ & $\begin{array}{c}\text { TB }^{+} \mathbf{H I V}^{+} \\
n=13\end{array}$ \\
\hline Age, years, median (range) & $58(46-78)$ & $36(18-64)$ \\
\hline \multicolumn{3}{|l|}{ Gender } \\
\hline Male & $6(75)$ & $6(46)$ \\
\hline Female & $2(25)$ & $7(54)$ \\
\hline \multicolumn{3}{|l|}{ Race } \\
\hline African & $5(63)$ & $13(100)$ \\
\hline Indian & $3(37)$ & 0 \\
\hline \multicolumn{3}{|l|}{ TB diagnostic criteria } \\
\hline Histopathology & & $1(8)$ \\
\hline Culture positive & & $8(62)$ \\
\hline Smear positive & & $3(23)$ \\
\hline PCR-MTBDR & & $8(62)$ \\
\hline Clinical with radiography & & $3(23)$ \\
\hline Resistance to any one first line TB drug & & $1(8)$ \\
\hline MDR-TB & & $1(8)$ \\
\hline XDR-TB & & 0 \\
\hline CD4 count, mm3, mean (range) & & $169(9-463)$ \\
\hline Past history of TB infection & 0 & $1(8)$ \\
\hline Current smoker & $3(37)$ & $2(15)$ \\
\hline Ex-smoker & $1(13)$ & 0 \\
\hline Alcohol use & $2(25)$ & $3(23)$ \\
\hline \multicolumn{3}{|l|}{ Definitive cause of $\mathrm{PE}$} \\
\hline Tuberculosis & 0 & $13(100)$ \\
\hline Malignancy & $5(63)$ & 0 \\
\hline End stage renal disease & $2(25)$ & 0 \\
\hline Heart failure & $1(13)$ & 0 \\
\hline \multicolumn{3}{|l|}{ Co-Morbidities } \\
\hline Diabetes mellitus & $3(37)$ & 0 \\
\hline Hypertension & $5(63)$ & $1(8)$ \\
\hline Hepatitis B & 0 & $2(15)$ \\
\hline
\end{tabular}

Values expressed as n (\%) unless otherwise stated

\subsection{Pleural Effusion Fluid and Mononuclear Cell Isolation}

Cell free pleural effusion fluid (PEF), pleural effusion mononuclear cells (PEMCs) and peripheral blood mononuclear cells (PBMCs) were extracted from heparinised pleural effusion fluid and blood by differential gradient centrifugation within 2 hours (h) of pleural tap/venipuncture. Briefly, $5 \mathrm{ml}$ 
of sample was layered onto equivolume Histopaque-1077 (catalogue number 10771-500, Sigma, USA) and centrifuged (1,491rpm, 30min, room temperature (RT)). PEF, represented as the uppermost layer, was aspirated and centrifuged $\left(10,000 \mathrm{rpm}, 10 \mathrm{~min}, 4^{\circ} \mathrm{C}\right)$ to remove any cellular constituents. Harvested PEF was pooled from 5 patients in each group equally and stored at $-80^{\circ} \mathrm{C}$ until further use. Buffy coats containing mononuclear cells were aspirated and rinsed in $0.1 \mathrm{M}$ phosphate buffered saline (PBS; 1,491rpm, 20min, RT).

\section{3 $\mathrm{CD4}^{+}$Cell Isolation}

For the in vitro component of the study, $\mathrm{CD}^{+}$conventional T-lymphocytes (Tconvs) were purified by negative magnetic selection from PBMCs of a healthy BCG vaccinated volunteer (10ml, EDTA, one blood draw), using the Human CD4 T-Lymphocyte Enrichment Set-DM (catalogue number 557939, BD Biosciences, USA), according to the manufacturer's instructions. PBMCs were labelled with biotinylated monoclonal antibodies $\left(5 \mu \mathrm{l} / 10 \times 10^{6}\right.$ cells, $\left.15 \mathrm{~min}, \mathrm{RT}\right)$ against antigens on erythrocytes, platelets and non-CD4 ${ }^{+}$peripheral leukocytes. The cells were washed (iMag Buffer, $1,491 \mathrm{rpm}, 20 \mathrm{~min})$ and incubated with streptavidin conjugated magnetic nanoparticles $\left(5 \mu 1 / 10 \times 10^{6}\right.$ cells, 30min, RT). The cell suspension was placed in a magnetic field (8min, iMagnet; BD Biosciences, USA) and the enriched $\mathrm{CD} 4^{+} \mathrm{T}$-cell supernatant aspirated. Negative selection of the positive fraction was performed three times to increase the yield of the enriched fraction. The purity of the enriched fraction was increased by further negative selection and assessed by flow cytometry.

\subsection{Cell Culture and Treatment}

Healthy $\mathrm{CD}^{+}{ }^{+}$-cells were seeded in triplicate $\left(8 \times 10^{4}\right.$ cells/well, U-bottomed microplate $)$ in PEF conditioned complete culture medium (CCM; RPMI 1640, 10\% foetal calf serum (FCS), $1 \%$ Penstrep-Fungizone, $1 \% \mathrm{~L}$-glutamine, final concentrations $)$ in a $1: 1$ ratio $\left(24 \mathrm{~h}, 37^{\circ} \mathrm{C}, 5 \% \mathrm{CO}_{2}\right)$. Treatments included $\mathrm{TB}^{-} \mathrm{HIV}^{-} \mathrm{PEF}$ and $\mathrm{TB}^{+} \mathrm{HIV}^{+} \mathrm{PEF}$. Concurrently, cells were activated with Dynabeads Human T-activator CD3/CD28 bead solution (catalogue number 11131D, Gibco, Norway) ( $2 \mu \mathrm{l} /$ well). Following incubation, cells were harvested, washed once $(0.1 \mathrm{M}$ PBS, 1,491rpm, 20min, RT) and the activation beads removed by magnetic selection (1 min, iMagnet). The supernatants were stored at $-80^{\circ} \mathrm{C}$ for downstream cytokine profiling and the cells immediately prepared for flow cytometric staining. 


\subsection{Flow Cytometric Analysis}

For surface staining, $2.5 \times 10^{5}$ cells were re-suspended in staining buffer $(25 \mu 1,0.1 \mathrm{M}$ PBS containing $1 \%$ heat inactivated FCS, $0.09 \%$ w/v sodium azide) and labelled with fluorescein isothiocyanate (FitC) anti-CD4 (1:5, catalogue number 555346) $\left(20 \mathrm{mins}, 4^{\circ} \mathrm{c}\right.$, in the dark). For intracellular staining, cells were fixed in 4\% paraformaldehyde $(500 \mu \mathrm{l}, 30 \mathrm{~min}, \mathrm{RT})$, washed (staining buffer; $1,491 \mathrm{rpm}, 20 \mathrm{~min}, \mathrm{RT})$, permeabilized in $75 \%$ cold methanol $\left(500 \mu \mathrm{l}, 10 \mathrm{~min},-20^{\circ} \mathrm{C}\right)$ and washed again. Cells were stained with the appropriate intracellular antibodies; peridin-chlorophyll-cyanin 5.5 (PerCP-Cy5.5) anti-IL17A (1:20, catalogue number 560799), phycoerythrin (PE) anti-RORC2 (1:40 catalogue number IC6006P) and Alex Fluor ${ }^{\circledR} 647$ anti-pSTAT3 (1:5 catalogue number 557815) (60min, RT, in the dark). Analysis was performed using the Accuri C6 flow cytometer (BD Biosciences, USA) and data analysed using FlowJo vX (10.0.7r2). Samples were run in triplicate and 30,000 events acquired. Antibodies were purchased from BD Biosciences, USA, with the exception of anti-RORC2 which was purchased from R\&D Systems.

\subsection{Molecular Profiling}

Total RNA was extracted from PEMCs using Qiazol Lysis Reagent (Qiagen, USA) following an inhouse protocol. Briefly, cells were added to Qiazol Lysis Reagent (1:1) and incubated at RT (5min) and subsequently frozen $\left(-80^{\circ} \mathrm{C}\right.$, overnight). Chloroform $(200 \mu \mathrm{l})$ was added, incubated at RT (3min) and centrifuged $\left(8,200 \mathrm{rpm}, 15 \mathrm{~min}, 4^{\circ} \mathrm{C}\right)$. Isopropanol $(500 \mu \mathrm{l})$ was added to the aqueous phase and frozen $\left(-80^{\circ} \mathrm{C}\right.$, overnight). The samples were centrifuged $\left(8,200 \mathrm{rpm}, 20 \mathrm{~min}, 4^{\circ} \mathrm{C}\right)$ and the RNA pellet washed in cold ethanol $(75 \%, 1 \mathrm{ml})$. The samples were then centrifuged $(6,400 \mathrm{rpm}, 15 \mathrm{~min}$, $4^{\circ} \mathrm{C}$ ), the ethanol aspirated and the RNA pellet re-suspended in $15 \mu$ l of nuclease free water. Total RNA was quantified on a Nanodrop ${ }^{\text {TM }} 2000$ UV-Vis Spectrophotometer (Thermoscientific, USA) and purity assessed using the $\mathrm{A}_{260} / \mathrm{A}_{280}$ ratio.

Copy DNA (cDNA) was synthesised using the $\mathrm{RT}^{2}$ First Strand Kit (catalogue number 330401, Qiagen, USA) according to the manufacturer's instructions. Briefly, $1 \mu \mathrm{g}$ of RNA pooled equally from 5 patients per group was added to a genomic DNA elimination mix $(5 \times$ gDNA elimination buffer, $\left.\mathrm{H}_{2} \mathrm{O}\right)$ to a total volume of $10 \mu \mathrm{l}$ and incubated at $42^{\circ} \mathrm{C}(5 \mathrm{~min})$ followed by $4{ }^{\circ} \mathrm{C}(1 \mathrm{~min})$. Subsequently, reverse transcription mix $(10 \mu 1,5 \times \mathrm{RT}$ buffer 3 , primer and external control mix, RT enzyme mix, $\left.\mathrm{H}_{2} 0\right)$ was added and incubated at $42^{\circ} \mathrm{C}(15 \mathrm{~min})$ followed by $95^{\circ} \mathrm{C}(5 \mathrm{~min})$, on the GeneAmp® PCR System 9700 (Applied Biosystems, USA), to produce cDNA. 
Real-time PCR was used to quantify STAT3, IL-6, IL-6R and IL-1 $\beta$ mRNA levels. A $25 \mu$ l reaction consisted of $12.5 \mu \mathrm{l} \mathrm{RT}^{2}$ SYBRGreen Masterrmix (catalogue number 330500, Qiagen, United States), $8.5 \mu \mathrm{l}$ nuclease free water, $2 \mu \mathrm{l} \mathrm{cDNA}$ and $1 \mu \mathrm{l}$ sense and anti-sense primers. Primer sequences: STAT3 sense 5'- TCTCAACTTCAGACCCGTCAACA-3' anti-sense 5'ACAGCTCCACGATTCTCTCCTCC-3' (450nM), IL-6 sense 5'AAATTCGGTACATCCTCGACGG-3' antisense 5'- GGAAGGTTCAGGTTGTTTTCTGC-3' (500nM), IL-6R sense 5'-TGAGCTCAGATATCGGGCTGAAC-3' antisense 5'CGTCGTGGATGACACAGTGATG-3' (450nM), IL-1 $\beta$ sense 5'CAGCTACGAATCTCCGACCAC-3' antisense 5'-GGCAGGGAACCAGCATCTTC-3' (600nM). The mRNA expression was compared and normalised to a housekeeping gene, 18S sense 5'TAGAATTACCACAGTTATCC-3' antisense 5'-TAGAATTACCACAGTTATCC-3'. Cycling conditions were as follows: initial denaturation $\left(95^{\circ} \mathrm{C}, 10 \mathrm{~min}\right)$ followed by 40 cycles of denaturation $\left(95^{\circ} \mathrm{C}, 30 \mathrm{~s}\right)$, annealing (STAT3: $64^{\circ} \mathrm{C}$, IL-6: $60^{\circ} \mathrm{C}$, IL-6R: $60^{\circ} \mathrm{C}$, IL-1 $\beta: 60^{\circ} \mathrm{C}$ for $30 \mathrm{~s}$ ) and extension $\left(72^{\circ} \mathrm{C}, 1 \mathrm{~min}\right)$ on a CFX Real-Time PCR Detector (Bio-Rad, USA).The quantification and melt curves were analysed using CFX Manager ${ }^{\text {TM }}$ Software v3.0 (Bio-Rad, USA). The mRNA levels were calculated using the method described by Livak and Schmittgen (2001) [15] and is represented as fold changes and relative expression to the control. Samples were run in triplicate and the experiments were repeated twice.

\subsection{Cytokine Profiling}

Cytokine profiling was performed using the Bio-Plex Pro Human Th17 Cytokine Panel (IL-1 $\beta$, IL4, IL-6, IL-10, IL-17A, IL-17F, IL-21, IL-22, IL-23, IL-25, IL-31, IL-33, IFN- $\gamma$, sCD40L, TNF- $\alpha$ ) (catalogue number 171AA001M, Bio-Rad, USA) according to the manufacturer's instructions. Briefly, standards and samples; PEF (1:6) and supernatant (1:3), were diluted in standard and sample diluent HB respectively. The beads $(50 \mu \mathrm{l})$ were added to the assay plate and washed twice (100 $\mu$ l wash buffer, Bio-Plex Pro ${ }^{\mathrm{TM}}$ Wash Station). Standards, samples and controls were added and incubated $(50 \mu \mathrm{l}, 1 \mathrm{~h}$ in the dark, RT, 350rpm). The plate was washed three times and incubated with detection antibody $(25 \mu 1,30 \mathrm{~min}$ in the dark, RT, 350rpm). The plate was washed three times and incubated with Streptavidin-PE (50 $1,10 \mathrm{~min}$ in the dark, RT, 350rpm). The plate was washed three

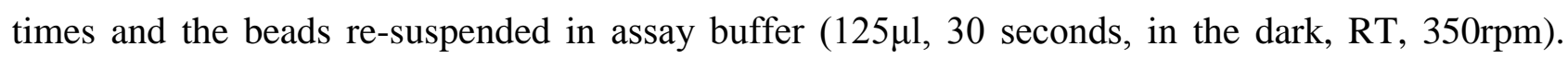
Data acquisition was performed on a Bio-Plex 200 and analysis was performed using Bio-Plex Manager ${ }^{\mathrm{TM}}$ software v6.0. Standards and samples were run in duplicate. Results were analysed using a 5-paramter logistic regression constructed from recombinant protein standards. The results were normalised to the treatment and then compared between groups. 


\subsection{Statistical Analysis}

Statistical analysis was performed using GraphPad Prism software (v5.0). The unpaired t-test with Welch correction was used in in vitro analyses and the non-parametric Mann-Whitney test in $e x$ vivo analyses to avoid the influence of potential outlier values in the small study size. Outlier values were calculated and excluded using the interquartile range. Data is expressed as mean \pm standard error of the mean (SEM), p values of less than 0.05 were considered statistically significant.

\section{3.}

\subsection{Reduced Proportion of Th17 Lymphocytes in a TB $^{+} \mathrm{HIV}^{+}$Pleurisy}

To investigate the propensity of TB/HIV co-infected pleural effusion microenvironment to promote Th17 generation we treated healthy $\mathrm{CD} 4^{+}$Tconvs with PEF conditioned CCM. Interestingly, we observed that the proportion of $\mathrm{CD} 4^{+} \mathrm{IL}-17^{+} \mathrm{RORC}^{+} \mathrm{STAT}^{+}$cells was significantly 1.168 fold lower in $\mathrm{CD}^{+}$Tconvs treated with $\mathrm{TB}^{+} \mathrm{HIV}^{+} \mathrm{PEF}$ compared to $\mathrm{TB}^{-} \mathrm{HIV}^{-} \mathrm{PEF}$ in vitro $(64.400 \pm 1.256 \%$ vs. $55.156 \pm 1.299 \%, p=0.0001)$. This trend was corroborated when Th17 proportion was directly investigated in patients. PEMC samples from $\mathrm{TB}^{+} \mathrm{HIV}^{+}$patients showed a significant 1.769 fold lower number of $\mathrm{CD}^{+} \mathrm{IL}^{-1} 7^{+} \mathrm{RORC}^{+} \mathrm{STAT}^{+}$cells compared to $\mathrm{TB}^{-} \mathrm{HIV}^{-}$controls $(64.100 \pm 5.045 \%$ vs. $36.233 \pm 6.968 \% p=0.0054)$, this was associated with a significant 1.575 fold decrease in IL17A protein expression ( $1454.000 \pm 117.167$ vs. $923.445 \pm 64.418 \mathrm{MFI}, p=0.0040)$ (Figure 1). 
A1

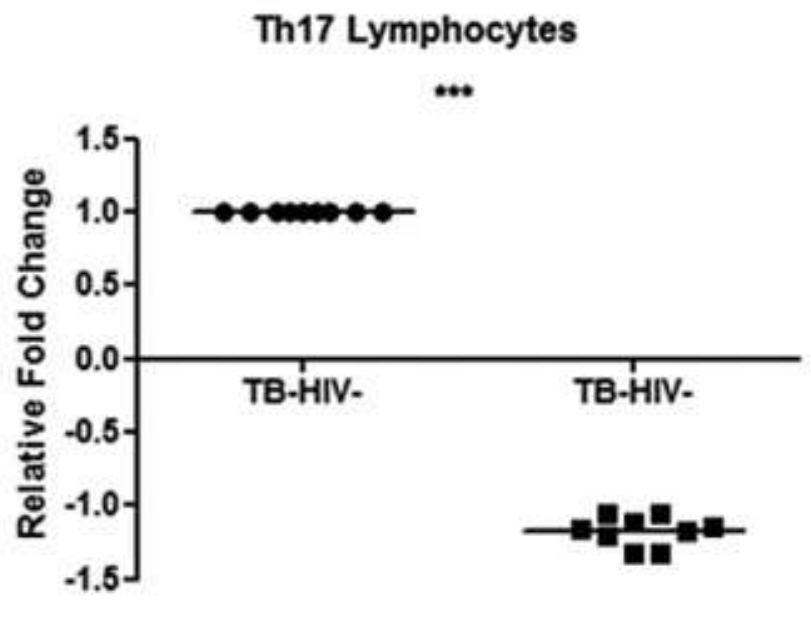

PEF Treated $\mathrm{CD4}^{+}$Cells

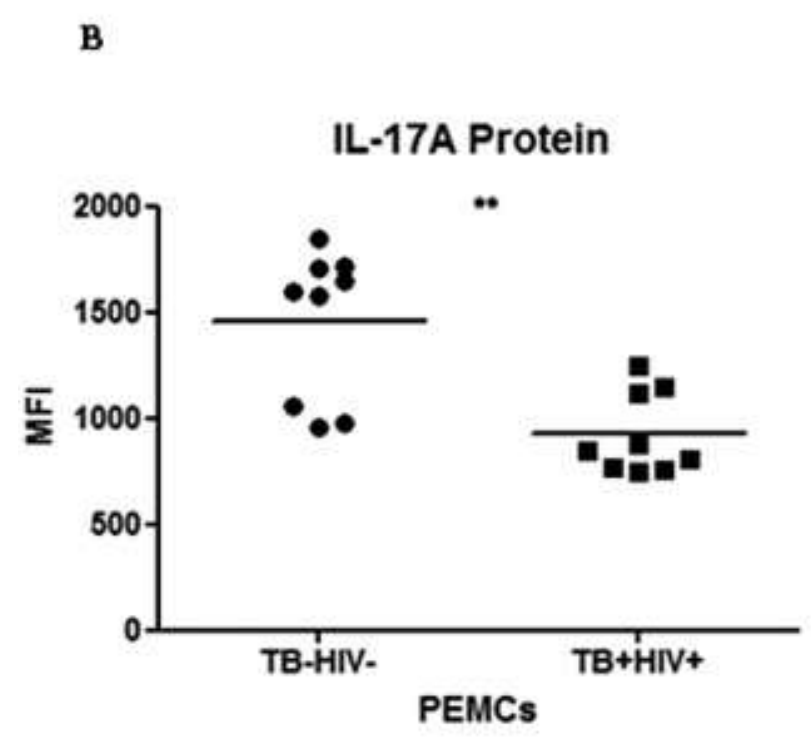

A2
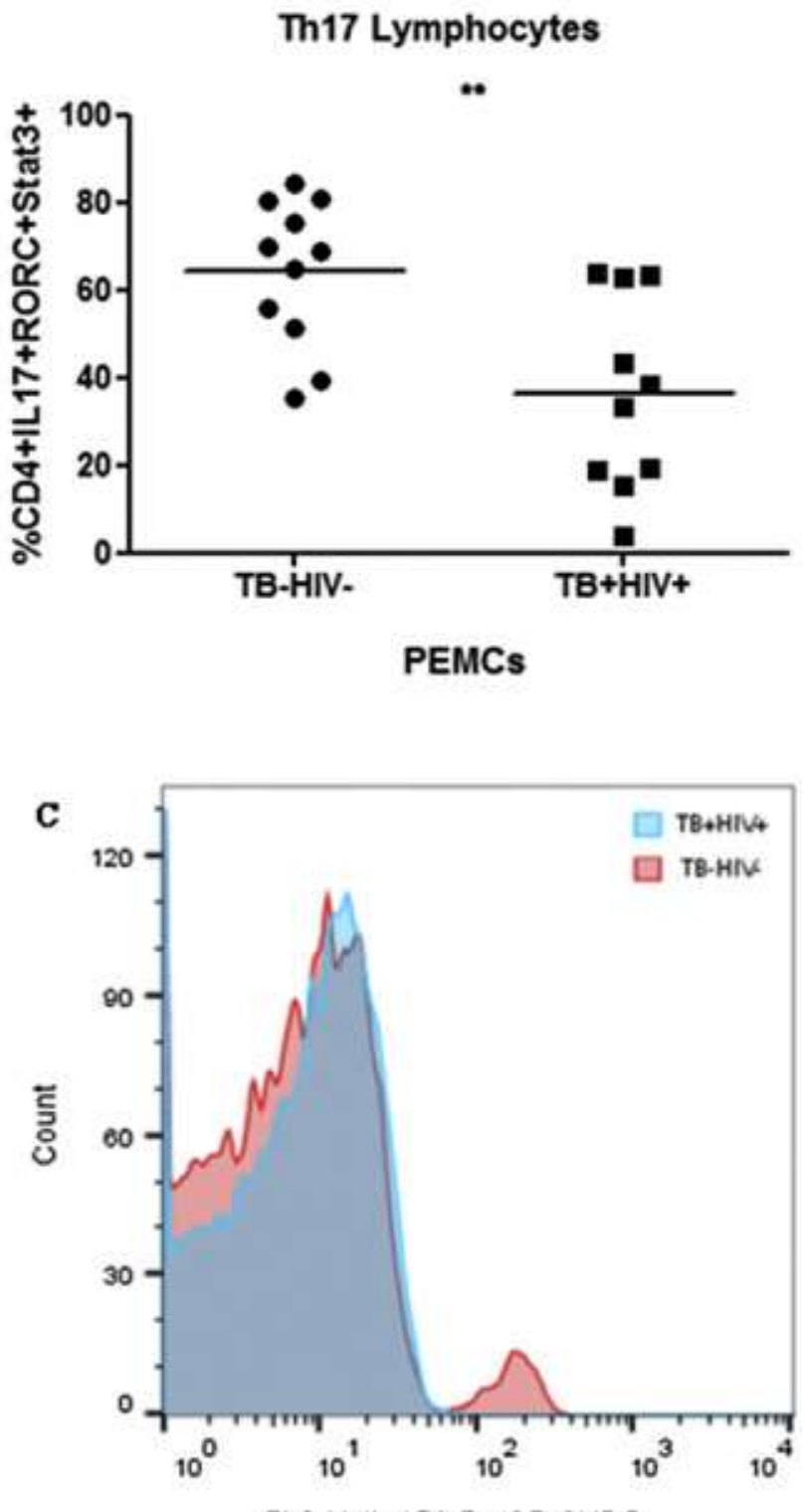

FL.3-H:IL-17A-PerCP-CY5.5

Figure 1: T-helper 17 lymphocyte frequency. (A1) Relative fold change in the proportion of $\mathrm{CD}^{+} \mathrm{IL}$ $17^{+}$RORC $^{+}$STAT3 $^{+}$T-helper (Th) 17 lymphocytes in pleural effusion fluid (PEF) treated $\mathrm{CD}^{+}$Tconvs in vitro $(n=9$ replicates in each group, $p=0.0001$, unpaired t-test with Welch correction). (A2) Reduced percentage of CD4 ${ }^{+} \mathrm{IL}$ $17^{+} \mathrm{RORC}^{+} \mathrm{STAT}^{+} \mathrm{Th}^{2} 7$ lymphocytes in pleural effusion mononuclear cells (PEMCs) ex vivo $\left(\mathrm{TB}^{-} \mathrm{HIV}^{-} n=5, \mathrm{~TB}^{+} \mathrm{HIV}^{+}\right.$ $n=5, p=0.0054$, Mann Whitney test). (B) Interleukin (IL)-17A protein expression was reduced in $\mathrm{TB}^{+} \mathrm{HIV}^{+} \mathrm{PEMCs}$ represented by peridin-chlorophyll-cyanin5.5 (PerCP-Cy5.5) mean fluorescence intensity (MFI) (TB-HIV ${ }^{-} n=5$, $\mathrm{TB}^{+} \mathrm{HIV}^{+} n=5, p=0.0040$, Mann Whitney test). (C) Histogram showing the shift in IL-7A-PerCP-Cy5.5 fluorescence in PEMCs. Data represents the mean.

\section{2 $\mathrm{TB}^{+} \mathrm{HIV}^{+}$Mediated Increase in mRNA Levels}

We then assessed the molecular response of PEMCs with respect to Th17 polarisation. PEMCs from $\mathrm{TB}^{+} \mathrm{HIV}^{+}$patients showed a significant upregulation in the transcript expression of molecules 
which promote Th17 differentiation; a notable 30.647 fold increase in STAT3 (17.037 \pm 0.089 vs $12.140 \pm 0.103$ relative expression $(\Delta \mathrm{Ct}), p=0.0022), 11.662$ fold increase in IL- $1 \beta(14.638 \pm 0.043$ vs. $11.102 \pm 0.035$ relative expression $(\Delta \mathrm{Ct}), p=0.0022), 3.076$ fold increase in IL-6 $(19.727 \pm 0.143$ vs. $18.380 \pm 0.284$ relative expression $(\Delta \mathrm{Ct}), p=0.0022)$ and a 1.657 fold increase in IL-6R $(18.752$ \pm 0.099 vs. $18.092 \pm 0.230$ relative expression $(\Delta \mathrm{Ct}), p=0.0247)$ (Figure 2).

Stat3

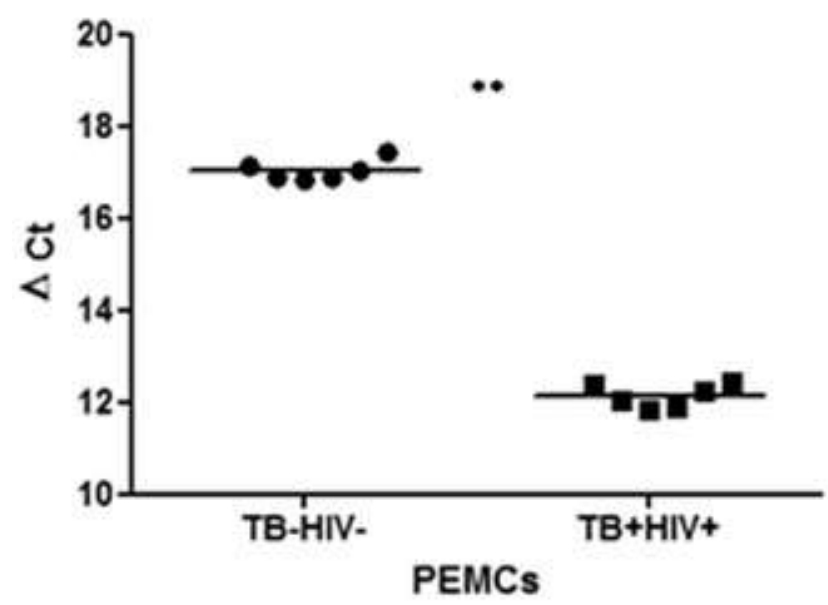

IL-6

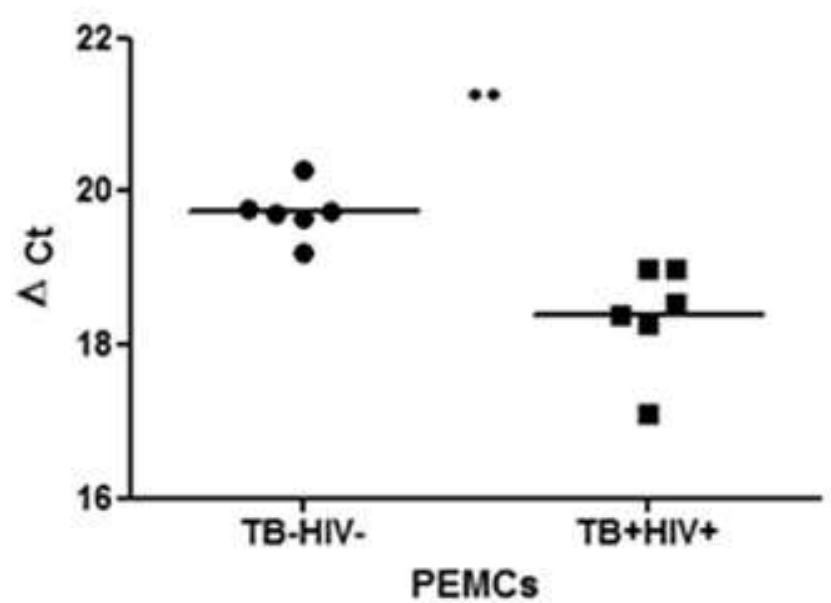

IL-1B

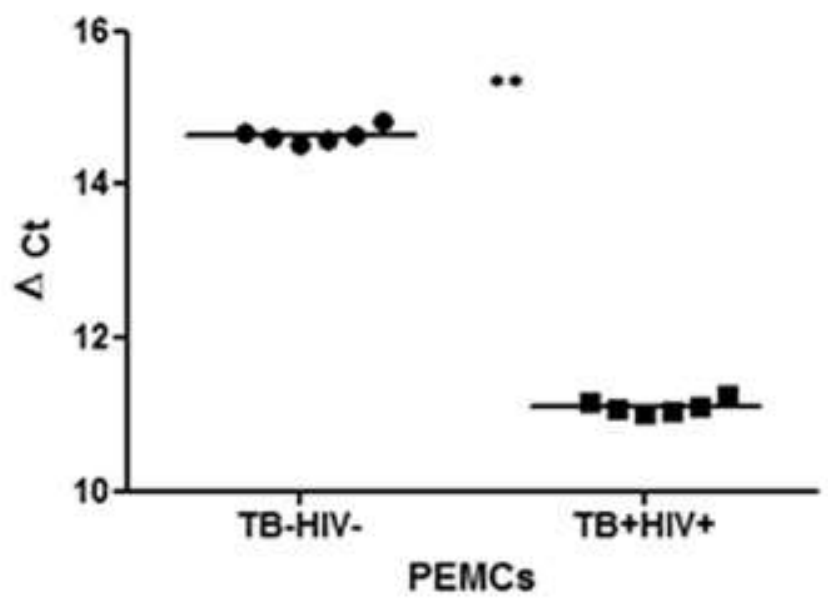

IL-6R

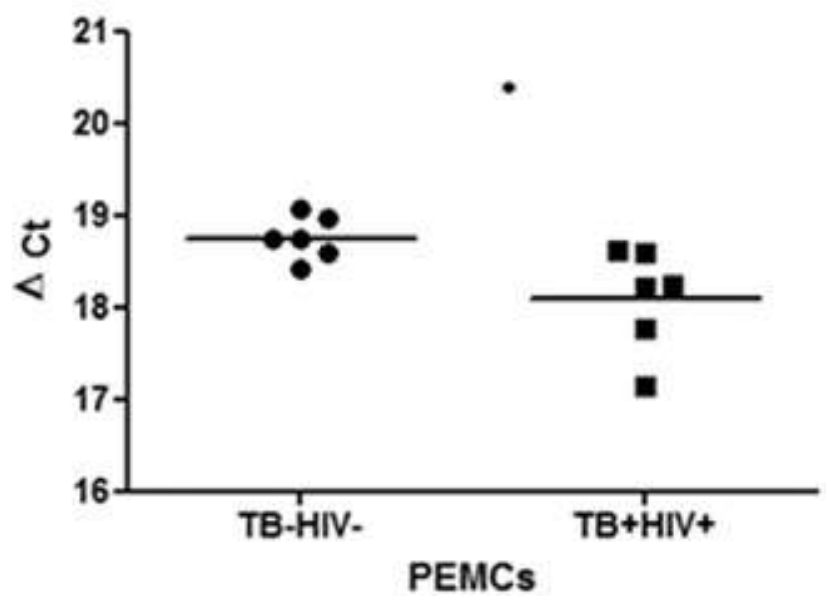

Figure 2: Relative mRNA expression $(\Delta \mathrm{Ct})$ in pooled pleural effusion mononuclear cells (PEMCs) ( $n=6$ replicates in each group, Mann-Whiney test). Signal transducer and activator of transcription 3 (STAT3) $p=0.0022$, interleukin (IL)$1 \beta p=0.0022$, IL-6 $p=0.0022$ and IL-6 receptor (IL-6R) $p=0.0247$. Data represents the mean.

\subsection{The TB $^{+}$HIV $^{+}$Cytokine Microenvironment}

Since we found increased expression of mRNA transcripts related to Th17 polarisation in $\mathrm{TB}^{+} \mathrm{HIV}^{+}$ PEMCs, we questioned whether in fact these were translated into secreted cytokine using a Bioplex multi-analyte cytokine screen. 


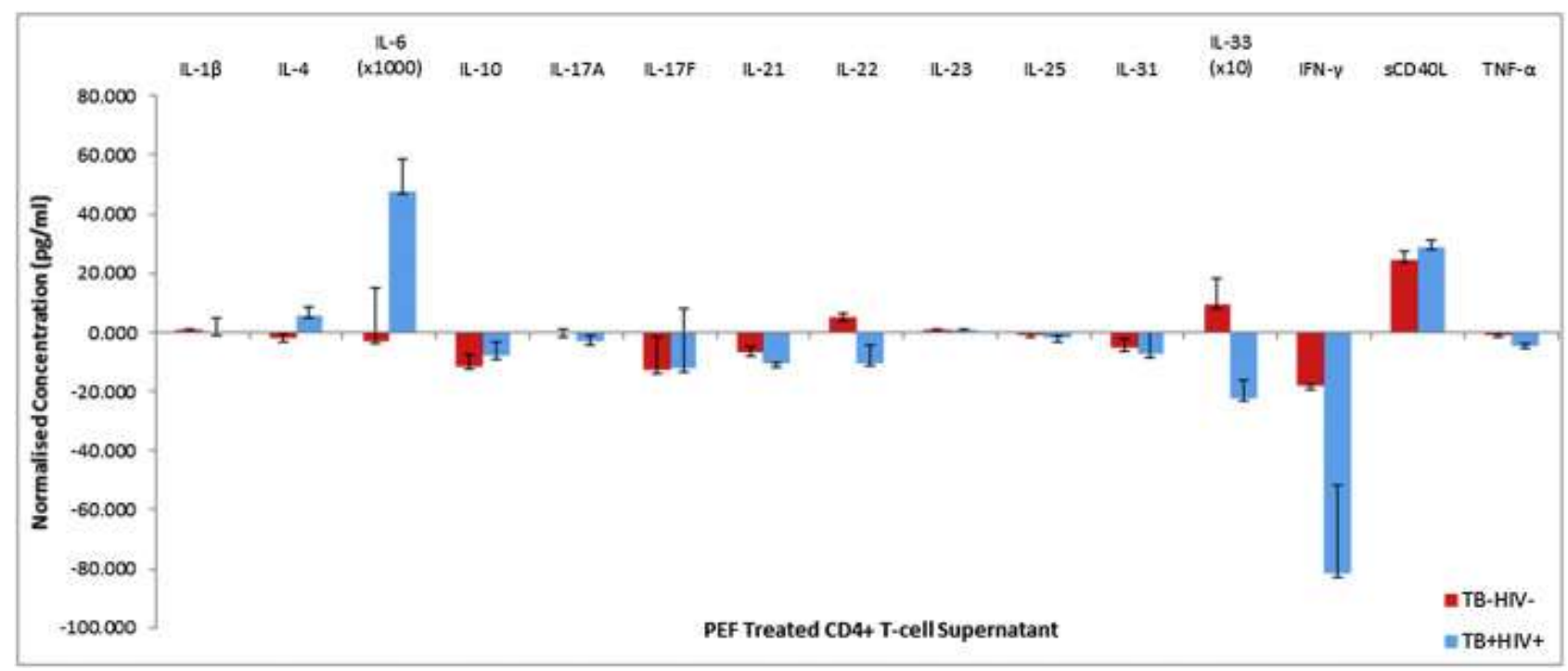

Figure 3: Cytokine profiling of supernatants from $\mathrm{CD}^{+} \mathrm{T}$-cells treated with pleural effusion fluid conditioned media. Results were normalised to the treating pleural effusion fluid (PEF) $\left(\mathrm{TB}^{-} \mathrm{HIV}^{-} n=2, \mathrm{~TB}^{+} \mathrm{HIV}^{+} \mathrm{n}=2\right.$, Unpaired $\mathrm{t}$-test with Welch correction). IL; interleukin, IFN; interferon, sCD40L; soluble CD40 ligand, TNF; tumor necrosis factor. Data represents the mean \pm SEM.

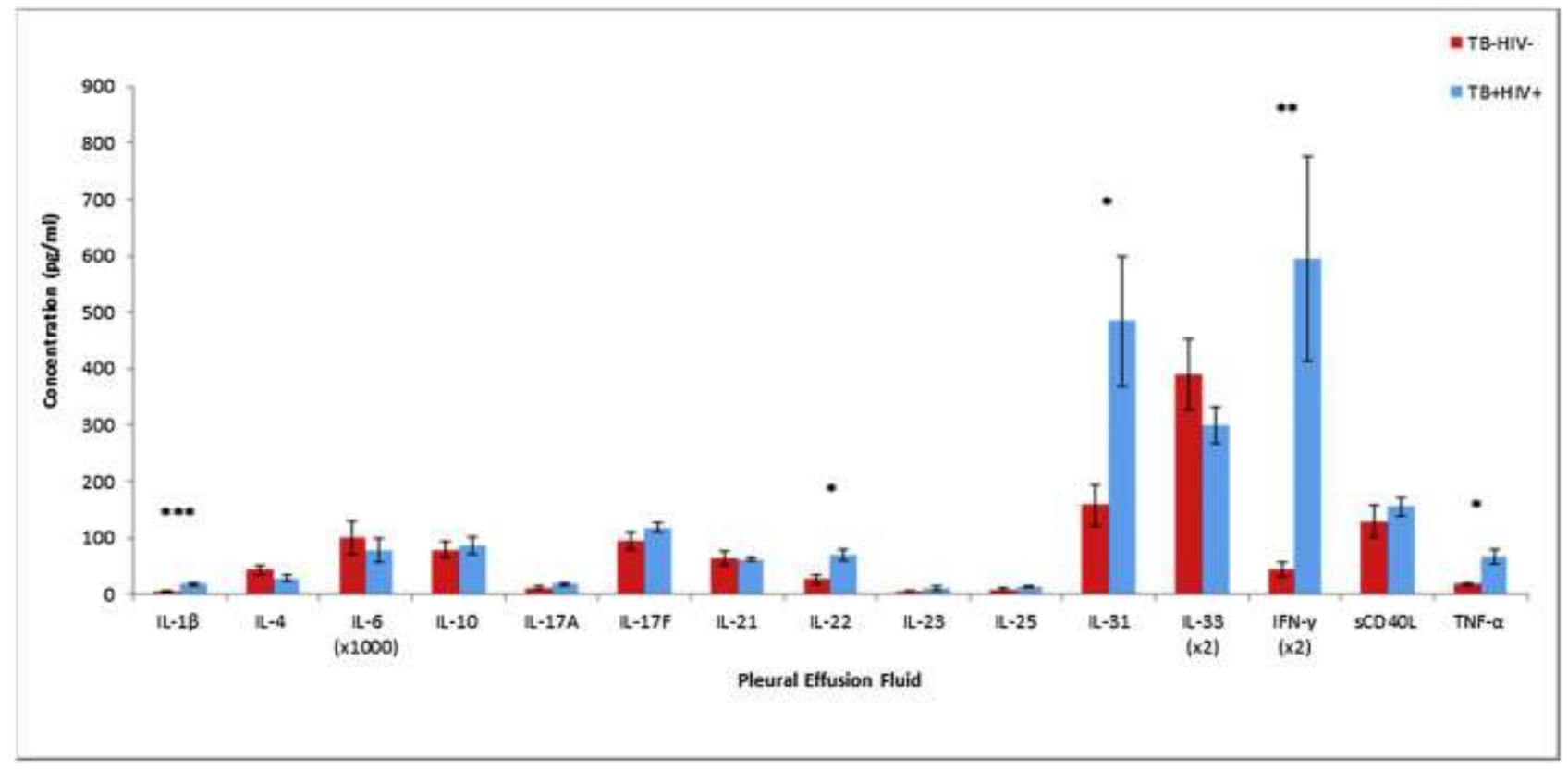

Figure 4: Cytokine profiling of pleural effusion fluid. $\mathrm{TB}^{+} \mathrm{HIV}^{+}$pleural effusion fluid (PEF) showed increased concentrations of interleukin (IL) $1 \beta p=0.0008$, IL-22 $p=0.0115$, IL-31 $p=0.0210$, interferon (IFN) $\gamma p=0.0026$ and tumor necrosis factor (TNF)- $\alpha p=0.0251$. (IL-1 $\beta$, IL-4, IL-6, IL-10, IFN- $\gamma$, TNF- $\alpha$; TB $^{-} \mathrm{HIV}^{-} n=8, \mathrm{~TB}^{+} \mathrm{HIV}^{+} \mathrm{n}=12$. IL17A, IL-17F, IL-21, IL-22, IL-23, IL-25, IL-31, IL-33, sCD40L; TBHIV ${ }^{-} n=5$, $\mathrm{TB}^{+} \mathrm{HIV}^{+} \mathrm{n}=5$, Mann-Whitney test). Data represents the mean \pm SEM. sCD40L; soluble CD40 ligand.

Despite the reduced frequency of Th17 cells in $\mathrm{TB}^{+} \mathrm{HIV}^{+} \mathrm{PEF}$ treatments and pleurisy, there was no significant change in the Th17 effector cytokines IL-17A and IL-17F concentrations in both the in vitro and ex vivo assays (Figure 3 and 4). Interestingly, in the $\mathrm{TB}^{+} \mathrm{HIV}^{+}$and $\mathrm{TB}^{-} \mathrm{HIV}^{-}$patient cohorts, IL-17F was elevated by 6.460 fold $(18.281 \pm 2.383 \mathrm{pg} / \mathrm{ml}$ vs. $118.090 \pm 8.077 \mathrm{pg} / \mathrm{ml}$, 
$p<0.0001)$ and 7.844 fold $(11.938 \pm 2.449 \mathrm{pg} / \mathrm{ml}$ vs. $93.637 \pm 15.357 \mathrm{pg} / \mathrm{ml}, \mathrm{p}=0.0009)$ compared to IL-17A respectively (Figure 4).

With respect to Th17 generating cytokines, there were no significant alteration between the $\mathrm{TB}^{+} \mathrm{HIV}^{+}$and $\mathrm{TB}^{-} \mathrm{HIV}^{-} \mathrm{PEF}$ treatments in vitro indicating that the reduced proportion of Th17 lymphocytes observed in $\mathrm{CD}^{+}{ }^{+}$Tconvs treated with $\mathrm{TB}^{+} \mathrm{HIV}^{+} \mathrm{PEF}$ was not a result of the cytokine milieu (Figure 3). In the patient samples, we observed a 3.708 fold increase in IL-1 $\beta$ (4.918 \pm $1.421 \mathrm{pg} / \mathrm{ml}$ vs. $18.238 \pm 3.064 \mathrm{pg} / \mathrm{ml}, p=0.0008$ ) but without a significant change in the levels of IL6, IL-21 or IL-23. This substantiates the in vitro result and infers that a reduced proportion of Th17 lymphocytes found in $\mathrm{TB}^{+} \mathrm{HIV}^{+}$pleurisy is independent of the cytokine microenvironment ex vivo (Figure 4).

Th-1 cytokines have established roles in TB and HIV pathogenesis, accordingly a 3.626 fold increase in TNF- $\alpha(18.233 \pm 2.615 \mathrm{pg} / \mathrm{ml}$ vs. $66.112 \pm 13.264 \mathrm{pg} / \mathrm{ml}, p=0.0251)$ and a 13.559 fold increase in IFN- $\gamma(87.792 \pm 27.282 \mathrm{pg} / \mathrm{ml}$ vs. $1190.386 \pm 361.906 \mathrm{pg} / \mathrm{ml}, p=0.0026)$ concentration was found in $\mathrm{TB}^{+} \mathrm{HIV}^{+} \mathrm{PEF}$ (Figure 4).

Notably, a 2.643 fold increase in IL-22 $(26.379 \pm 8.903 \mathrm{pg} / \mathrm{ml}$ vs. $69.729 \pm 10.318 \mathrm{pg} / \mathrm{ml}, p=0.0115)$ and a 3.055 fold increase in IL-31 (158.430 $\pm 35.615 \mathrm{pg} / \mathrm{ml}$ vs. $483.957 \pm 115.651 \mathrm{pg} / \mathrm{ml}, p=0.0210)$ was observed, both of which are largely uncharacterised in TB and HIV infection (Figure 4).

\section{DISCUSSION}

The Th17/IL17 axis is suggested to provide protective immunity against MTB by contributing to development and organisation of the granuloma. Early expression of pulmonary IL-17 in primary infection is pivotal in cellular recruitment by inducing chemokine secretion from nonhaematopoietic cells. This predominantly results in neutrophil and CCR5 ${ }^{+}$lymphocyte recruitment, through the induction of IL-8 and chemokine C-X-C motif ligand (CXCL) 13 respectively, to form lung lymphoid follicles for optimal macrophage activation and bacterial clearance [16, 17]. However, during the chronic stages of infection, Th17 hyperactivity can lead to immunopathology via IL-17-CXCL mediated influx of immune cells, breakdown of the granuloma, cavitation and transmission [18]. Th17 immunity has also been shown to contribute to mucosal TB vaccine immunity by IL-17A induction of CXCL13 [16]. However, there is no consensus on the proportion of Th17 cells in TB infection and the significance of this contribution to disease pathogenesis. 
This is further confounded by HIV co-infection. Th17 cells show greater HIV susceptibility than other T-cell subsets. Th17 lymphocyte targeting has been correlated with a higher expression of HIV envelope receptors CD4, CXCR4, CCR5 and $\alpha 4 \beta 7$ and low levels of autocrine production of CCR5 ligands CCL3 and CCL4, resulting in higher gp120 binding [19]. This is associated with a significant impairment in the generation of Th17 cells from peripheral naïve CD4 ${ }^{+}$T-cells [11]. In addition, the over expression of negative regulators in Th17 differentiation (phosphatase SHP2, suppressor of cytokine signalling (SOCS) 3 and protein inhibitor of activated STAT3 (PIAS3)) have been linked to Th17 deficiency in a simian immunodeficiency virus (SIV) model [20]. Notably, HIV-1 infected long-term non-progressors [10] preserve the Th17 subset in peripheral blood and mucosa.

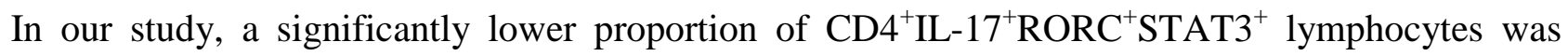
found in $\mathrm{TB}^{+} \mathrm{HIV}^{+}$pleurisy compared to $\mathrm{TB}^{-} \mathrm{HIV}^{-}$pleurisy both in vitro and ex vivo. Classically, Th17 cells differentiate under TGF- $\beta /$ IL-21 or TGF- $\beta /$ IL-6 and IL-21/IL-23 [21] conditions. This leads to Th17 lineage commitment via the activation of STAT3 and downstream transcription factor RORC, as well as interferon regulating factor 4 (IRF4), which in turn bind to the promoter region of $I L 17 A / F$ [22]. Further to this IL-1 $\beta$ and IL-6 are significant in the expansion of differentiated and memory Th17 cells and IL-23 for the stabilisation and maintenance of the Th17 phenotype and effector functions [23]. Despite the reduction in Th17 frequency, there was no significant difference in the concentrations of IL-6, IL-21, and IL-23 between the two groups both in vitro and ex vivo indicating that the reduced proportion of Th17 cells is not a result of decreased polarising cytokines. In support of this, previous studies have shown that HIV infection is characterised by high levels of TGF- $\beta$ [24], IL-6 [25] and IL-1 [12] suggesting that failure to generate Th17 cells is not due to a lack of promoting cytokines.

Notably, $\mathrm{TB}^{+} \mathrm{HIV}^{+}$pleurisy was associated with a significant 3.708 fold increase in IL-1 $\beta$ pleural fluid concentration and a 11.662 fold increase in IL-1 $\beta$ mRNA levels in PEMCs. Th17 cells express higher IL-1R levels than other CD4 subsets [26], in turn IL-1 $\beta$ upregulates the expression of transcription factors IRF4 and RORC and acts synergistically with IL-6, IL-23 and TGF- $\beta$ to stimulate Th17 differentiation and maintain IL-17A, IL-17F, IL-21 and IL-22 cytokine production in effector cells $[22,26]$. Very recently, a clinical isolate of the hypervirulent W-Beijing strain of MTB has been shown to induce a potent IL-17 protective response in a murine model through the induction of dendritic cell IL-1 $\beta$ and the subsequent formation of lung lymphoid follicles [16]. Furthermore, it was shown that blocking of IL-1/IL-1R signalling led to almost complete inhibition 
of IL-17A production during MTB stimulation in PBMCs [27]. Our results indicate that Th17 lymphocytes in TB/HIV pleurisy may be defective in their ability to respond to IL-1 $\beta$.

In the current study we found a 1.657 and 3.076 fold increase in IL-6R and IL-6 mRNA levels in co-infection, respectively but no increase in IL-6 cytokine levels in pleural fluid. This was interesting as recently the upregulation of IL-6 has been identified as a potential biomarker of mycobacterial infection in vitro [28]. During active TB infection IL-6 levels are increased in plasma and broncho-alveolar lavage (BAL) fluid with positive correlation to disease severity [29]. Furthermore, IL-6 is noted to be elevated in all phases of HIV chronic infection and a clinical trial has shown that increased IL-6 levels are associated with increased all-cause mortality in HIV [30]. Our findings suggest that post transcriptional regulation of key Th17 polarising cytokines may influence the cytokine microenvironment.

Despite a significant decrease in the frequency of $\mathrm{Th} 17$ cells in $\mathrm{TB}^{+} \mathrm{HIV}^{+}$pleurisy, there was no significant difference in the concentration of effector cytokines IL-17A and IL-17F between the two groups in vitro and ex vivo. In line with our findings, it has been observed that IL-17 mRNA levels in BAL cells of active TB patients and healthy controls do not differ significantly [31]. This may be a result of IL-17A production by $\mathrm{CD} 8^{+} \mathrm{T}$-cells [32], yöT-cells [33, 34], natural killer cells [35], neutrophils [36] and innate lymphoid cells [37]. The contribution of these different cell types to IL-17 associated diseases is still unknown [17]. yöT-cells, enriched at mucosal surfaces, such as the lung, have been indicated as a major source of early IL-17A production in response to MTB $[33,34]$ and found to be at significantly higher frequency in the peripheral blood of active TB patients compared to healthy donors [34]. $\gamma$ öT-cells can respond to IL-23 and IL-1 $\beta$ amplifying Th17 responses [33] and therefore it is possible that the IL-17 observed in $\mathrm{TB}^{+} \mathrm{HIV}^{+}$pleurisy may be a result of a IL-1 $\beta$ - $\gamma$ öT-cell pathway.

Notably, IL-17F was present at a significantly higher concentration than IL-17A in both $\mathrm{TB}^{+} \mathrm{HIV}^{+}$ and $\mathrm{TB}^{-} \mathrm{HIV}^{-}$groups, 6.460 and 7.844 fold respectively. IL-17F alone is generally less inflammatory than IL-17A; however, its effects are augmented when combined with TNF- $\alpha$ [38], also significantly increased in $\mathrm{TB}^{+} \mathrm{HIV}^{+} \mathrm{PEF}$. In support of our results, a previous study noted a decreased frequency of IL-17A producing $\mathrm{CD}^{+}$T-cells but increased frequency of IL-17F producing $\mathrm{CD}^{+}$T-cells in the peripheral blood of HIV infected patients [39], implying a HIV mediated selective defect in IL-17A production. 
TNF- $\alpha$ and IFN- $\gamma$ have established roles in the pathogenesis of TB and HIV, their significantly increased expression observed in $\mathrm{TB}^{+} \mathrm{HIV}^{+}$pleurisy is not unexpected. IFN- $\gamma$ is the preeminent cytokine in MTB immune defence, its primary function is the activation of macrophages instituting mycobacterial killing mechanisms [40] which is enhanced by TNF- $\alpha$ [41]. HIV-1 Tat protein induces production of TNF- $\alpha$ and IFN- $\gamma$ in human monocytes/macrophages, in turn these cytokines synergistically stimulate HIV replication in vitro [42]. This suggests that in co-infection TNF- $\alpha$ and IFN- $\gamma$ provide protective immunity against MTB but promote replication of HIV indicating that defence against one pathogen allows injury by another. Furthermore, IFN- $\gamma$ has been shown to limit the size of the Th17 population during MTB infection [43]. In our $\mathrm{TB}^{+} \mathrm{HIV}^{+}$cohort we observed significantly a higher concentration of IFN- $\gamma$ over IL-17A (65.116 fold increase, $p=0.0006)$ or IL$17 \mathrm{~F}$ (10.080 fold increase, $p=0.0092$ ) possibly contributing to the reduction in Th17 lymphocytes in co-infection.

Our investigations showed a 2.643 fold increase in IL-22 levels in $\mathrm{TB}^{+} \mathrm{HIV}^{+}$pleurisy. IL-22 has been implicated in pathogenesis of TB [7, 44] and HIV [45]. However, it remains to be determined if IL-22 is involved in protective or pathogenic immunity in co-infection or the reparative process following the immuno-pathological consequences of these diseases. IL-22 significantly exceeded the concentration of IL-17A (3.814 fold, $p<0.0001$ ) but not IL-17F in $\mathrm{TB}^{+} \mathrm{HIV}^{+}$pleurisy. This is in line with previous work where IL-22 was found to surpass IL-17A in $\mathrm{TB}^{+}$pleural fluid [44]. The raised level of IL-22 in the face of decreased frequency in Th17 cells could represent contribution by other cell types, including innate lymphoid cells [46]. In this regard, during experimental MTB infection, IL-22 was found to be predominantly produced by Th1 and Th22 cells rather than Th17 cells [47]. IFN- $\gamma$ suppresses PBMC IL-17A production and Th17 activity but not IL-22 production $[7,47]$ allowing for effective IL-22 production in the absence of Th17 cells, in line with our results.

The 3.055 fold increase in IL-31 concentration in $\mathrm{TB}^{+} \mathrm{HIV}^{+}$pleurisy is novel. IL-31 is generally associated with Th2 mediated skin inflammation or allergic responses in the airways and GIT and has not been characterised in TB/HIV co-infection or mono-infection. IL-31 mRNA is upregulated in the lungs after antigen challenge, the targets of which are primarily bronchial epithelial cells, pulmonary fibroblasts and macrophages where it upregulates pro-inflammatory cytokine and chemokine gene expression involved in cellular recruitment [48], in the context of TB this may contribute to granuloma organisation. IL-31 can also directly inhibit IL-17A/F mRNA synthesis in Th17 cells through the regulation of PIAS molecules [49] possibly augmenting the observed decrease in Th17 frequency. 
In HIV infection, the depletion of Th17 cells at the mucosal surface is associated with increased translocation of microbial into the systemic circulation rendering a patient more prone to opportunistic infections and suggested to be a predominant cause of chronic immune activation and HIV progression $[12,50]$. At the respiratory mucosa, a loss of Th17 cells decreases mucosal defence to inhaled MTB and together with reduced IL-17-mediated cellular recruitment and granuloma organisation may result in the progression of active TB infection.

\section{CONCLUDING REMARKS}

A reduced proportion of Th17 cells were observed in $\mathrm{TB}^{+} \mathrm{HIV}^{+}$pleurisy independent of alteration in the levels of Th17 polarising cytokines and IL-17A/F effector cytokines in the localised microenvironment.

\section{ACKNOWLEDGEMENTS}

Conflicts of interest: none. The authors acknowledge financial support from the National Research Foundation, KwaZulu-Natal Research Institute for Tuberculosis and HIV and College of Health Sciences, University of KwaZulu-Natal.

\section{REFERENCES}

1. Huber S, Gagliani N, Flavell RA. Life, death, and miracles: Th17 cells in the intestine. Eur J Immunol 2012; 42:2238-45.

2. Zhou X, Chen Q, Moore J, Kolls JK, Halperin S, Wang J. Critical role of the interleukin17/interleukin-17 receptor axis in regulating host susceptibility to respiratory infection with chlamydia species. Infect Immun 2009; 77:5059-70.

3. Kudva A, Scheller EV, Robinson KM, Crowe CR, Choi SM, Slight SR, et al. Influenza A inhibits Th17-mediated host defense against bacterial pneumonia in mice. J Immunol 2011; 186:1666-74.

4. Schoenen H, Bodendorfer B, Hitchens K, Manzanero S, Werninghaus K, Nimmerjahn F, et al. Cutting edge: Mincle is essential for recognition and adjuvanticity of the mycobacterial cord factor and its synthetic analog trehalose-dibehenate. J Immunol 2010; 184:2756-60. 
5. Jurado JO, Pasquinelli V, Alvarez IB, Peña D, Rovetta AI, Tateosian NL, et al. IL-17 and IFN- $\gamma$ expression in lymphocytes from patients with active tuberculosis correlates with the severity of the disease. J Leukoc Biol 2012; 91:991-1002.

6. Wang GQ, Yang CL, Yue DF, Pei LH, Zhong H, Niu JX. The changes and its significance of Th17 and Treg cells and related cytokines in patients with tuberculosis pleurisy. Allergy Asthma Clin Immunol 2014; 10:28-33.

7. Scriba TJ, Kalsdorf B, Abrahams D-A, Isaacs F, Hofmeister J, Black G, et al. Distinct, specific IL-17-and IL-22-producing $\mathrm{CD}^{+}{ }^{+}$-cell subsets contribute to the human antimycobacterial immune response. J Immunol 2008; 180:1962-70.

8. Bandaru A, Devalraju KP, Paidipally P, Dhiman R, Venkatasubramanian S, Barnes PF, et al. Phosphorylated STAT3 and PD-1 regulate IL-17 production and IL-23 receptor expression in Mycobacterium tuberculosis infection. Eur J Immunol 2014; 44:2013-24.

9. Chatterjee D, Pramanik AK. Tuberculosis in the African continent: A comprehensive review. Pathophysiol 2015; 22:73-83.

10. Ciccone EJ, Greenwald JH, Lee PI, Biancotto A, Read SW, Yao MA, et al. CD4 ${ }^{+}$T-cells, including Th17 and cycling subsets, are intact in the gut mucosa of HIV-1-infected longterm nonprogressors. J Virol 2011; 85:5880-8.

11. DaFonseca S, Niessl J, Pouvreau S, Wacleche VS, Gosselin A, Cleret-Buhot A, et al. Impaired Th17 polarization of phenotypically naive $\mathrm{CD}^{+}{ }^{+} \mathrm{T}$-cells during chronic HIV-1 infection and potential restoration with early ART. Retrovirology 2015; 12:38-60.

12. Bixler SL, Mattapallil JJ. Loss and dysregulation of Th17 cells during HIV infection. Clin Dev Immunol 2013; 2013:e852418.

13. Barker RD. Clinical tuberculosis. Medicine 2012; 40:340-5.

14. Gideon HP, Phuah J, Myers AJ, Bryson BD, Rodgers MA, Coleman MT, et al. Variability in tuberculosis granuloma $\mathrm{T}$-cell responses exists, but a balance of pro-and antiinflammatory cytokines is associated with sterilization. PLoS Pathog 2015; 11:e1004603.

15. Livak KJ, Schmittgen TD. Analysis of relative gene expression data using real-time quantitative PCR and the 2(-Delta Delta C(T)) Method. Methods 2001; 25:402-8.

16. Gopal R, Rangel-Moreno J, Slight S, Lin Y, Nawar HF, Junecko BF, et al. Interleukin-17dependent CXCL13 mediates mucosal vaccine-induced immunity against tuberculosis. Mucosal Immunol 2013; 6:972-84.

17. Miossec P, Kolls JK. Targeting IL-17 and Th17 cells in chronic inflammation. Nat Rev Drug Discov 2012; 11:763-76. 
18. Cruz A, Fraga AG, Fountain JJ, Rangel-Moreno J, Torrado E, Saraiva M, et al. Pathological role of interleukin 17 in mice subjected to repeated BCG vaccination after infection with Mycobacterium tuberculosis. J Exp Med 2010; 207:1609-16.

19. Alvarez Y, Tuen M, Shen G, Nawaz F, Arthos J, Wolff MJ, et al. Preferential HIV infection of CCR6 ${ }^{+}$Th17 cells is associated with higher levels of virus receptor expression and lack of CCR5 ligands. J Virol 2013; 87:10843-54.

20. Bixler SL, Sandler NG, Douek DC, Mattapallil JJ. Suppressed Th17 levels correlate with elevated PIAS3, SHP2, and SOCS3 expression in CD4 T-cells during acute simian immunodeficiency virus infection. J Virol 2013; 87:7093-101.

21. Manel N, Unutmaz D, Littman DR. The differentiation of human Th17 cells requires transforming growth factor- $\beta$ and induction of the nuclear receptor ROR- $\gamma$ t. Nat Immunol 2008; 9:641-9.

22. Brüstle A, Heink S, Huber M, Rosenplänter C, Stadelmann C, Yu P, et al. The development of inflammatory Th17 cells requires interferon-regulatory factor 4. Nat Immunol 2007; 8:958-66.

23. Yang XO, Pappu BP, Nurieva R, Akimzhanov A, Kang HS, Chung Y, et al. T-helper 17 lineage differentiation is programmed by orphan nuclear receptors $\operatorname{ROR} \alpha$ and $\operatorname{ROR} \gamma$. Immunity 2008; 28:29-39.

24. Lotz M, Seth P. TGF- $\beta$ and HIV infection. Ann N Y Acad Sci 1993; 685:501-11.

25. Nixon DE, Landay AL. Biomarkers of immune dysfunction in HIV. Curr Opin HIV AIDS 2010; 5:498.

26. Lee W-W, Kang SW, Choi J, Lee S-H, Shah K, Eynon EE, et al. Regulating human Th17 cells via differential expression of IL-1 receptor. Blood 2010; 115:530-40.

27. van de Veerdonk FL, Teirlinck AC, Kleinnijenhuis J, Kullberg BJ, van Crevel R, van der Meer JW, et al. Mycobacterium tuberculosis induces IL-17A responses through TLR4 and dectin-1 and is critically dependent on endogenous IL-1. J Leukoc Biol 2010; 88:227-32.

28. Singh PP, Goyal A. Interleukin-6: A potent biomarker of mycobacterial infection. Springerplus 2013; 2:686.

29. Tsao TCY, Hong J, Huang C, Yang P, Liao SK, Chang KSS. Increased TNF- $\alpha$, IL-1 $\beta$ and IL-6 levels in the bronchoalveolar lavage fluid with the upregulation of their mRNA in macrophages lavaged from patients with active pulmonary tuberculosis. Tuber Lung Dis 1999; 79:279-85.

30. Kuller LH, Tracy R, Belloso W, De Wit S, Drummond F, Lane HC, et al. Inflammatory and coagulation biomarkers and mortality in patients with HIV infection. PLoS Med 2008; $5: \mathrm{e} 203$. 
31. Dheda K, Chang J, Lala S, Huggett J, Zumla A, Rook G. Gene expression of IL-17 and IL23 in the lungs of patients with active tuberculosis. Thorax 2008; 63:566-8.

32. Happel KI, Zheng M, Young E, Quinton LJ, Lockhart E, Ramsay AJ, et al. Cutting edge: Roles of Toll-like receptor 4 and IL-23 in IL-17 expression in response to Klebsiella pneumoniae infection. J Immunol 2003; 170:4432-6.

33. Lockhart E, Green AM, Flynn JL. IL-17 production is dominated by $\gamma \delta \mathrm{T}$ cells rather than CD4 T-cells during Mycobacterium tuberculosis infection. J Immunol 2006; 177:4662-9.

34. Peng M, Wang Z, Yao C, Jiang L, Jin Q, Wang J, et al. Interleukin 17-producing $\gamma \delta$ T-cells increased in patients with active pulmonary tuberculosis. Cell Mol Immunol 2008; 5:203-8.

35. Michel M-L, Keller AC, Paget C, Fujio M, Trottein F, Savage PB, et al. Identification of an IL-17-producing NK1. 1' ${ }^{-}$iNKT cell population involved in airway neutrophilia. J Exp Med 2007; 204:995-1001.

36. Ferretti S, Bonneau O, Dubois GR, Jones CE, Trifilieff A. IL-17, produced by lymphocytes and neutrophils, is necessary for lipopolysaccharide-induced airway neutrophilia: IL-15 as a possible trigger. J Immunol 2003; 170:2106-12.

37. Takatori H, Kanno Y, Watford WT, Tato CM, Weiss G, Ivanov II, et al. Lymphoid tissue inducer-like cells are an innate source of IL-17 and IL-22. J ExpMed 2009; 206:35-41.

38. Zrioual S, Ecochard R, Tournadre A, Lenief V, Cazalis M-A, Miossec P. Genome-wide comparison between IL-17A-and IL-17F-induced effects in human rheumatoid arthritis synoviocytes. J Immunol 2009; 182:3112-20.

39. Salem M, Ronit A, Gaardbo JC, Lund TT, Ullum H, Gerstoft J, et al. Altered balance between IL-17A- and IL-17F-producing Th17 cells in HIV-infected patients. J Acquir Immune Defic Syndr 2013; 63:e28-30.

40. Cavalcanti YVN, Brelaz MCA, Neves JKdAL, Ferraz JC, Pereira VRA. Role of TNF- $\alpha$, IFN- $\gamma$, and IL-10 in the development of pulmonary tuberculosis. Pulm Med 2012; 2012:e745483.

41. Stenger S. Immunological control of tuberculosis: Role of tumour necrosis factor and more. Ann Rheum Dis 2005; 64:24-8.

42. Haij NB, Leghmari K, Planès R, Thieblemont N, Bahraoui E. HIV-1 Tat protein binds to TLR4-MD2 and signals to induce TNF- $\alpha$ and IL-10. Retrovirology 2013; 10:123-34.

43. Cruz A, Khader SA, Torrado E, Fraga A, Pearl JE, Pedrosa J, et al. Cutting edge: IFN- $\gamma$ regulates the induction and expansion of IL-17-producing CD4 T-cells during mycobacterial infection. J Immunol 2006; 177:1416-20. 
44. Matthews K, Wilkinson KA, Kalsdorf B, Roberts T, Diacon A, Walzl G, et al. Predominance of interleukin-22 over interleukin-17 at the site of disease in human tuberculosis. Tuberculosis 2011; 91:587-93.

45. Missé D, Yssel H, Trabattoni D, Oblet C, Lo Caputo S, Mazzotta F, et al. IL-22 participates in an innate anti-HIV-1 host resistance network through acute-phase protein induction. $J$ Immunol 2007; 178:407-15.

46. Eberl G, Di Santo JP, Vivier E. The brave new world of innate lymphoid cells. Nat Immunol $2015 ; 16: 1-5$.

47. Behrends J, Renauld J-C, Ehlers S, Hölscher C. IL-22 is mainly produced by IFN- $\gamma$ secreting cells but is dispensable for host protection against Mycobacterium tuberculosis infection. PLoS One 2013; 8:e57379.

48. Horejs-Hoeck J, Schwarz H, Lamprecht S, Maier E, Hainzl S, Schmittner M, et al. Dendritic cells activated by IFN- $\gamma /$ STAT1 express IL-31 receptor and release proinflammatory mediators upon IL-31 treatment. J Immunol 2012; 188:5319-26.

49. Zhang Q, Putheti P, Zhou Q, Liu Q, Gao W. Structures and biological functions of IL-31 and IL-31 receptors. Cytokine Growth Factor Rev 2008; 19:347-56.

50. Brenchley JM, Price DA, Schacker TW, Asher TE, Silvestri G, Rao S, et al. Microbial translocation is a cause of systemic immune activation in chronic HIV infection. Nat Med 2006; 12:1365-71. 